\title{
Z-DNA Binding Protein
}

National Cancer Institute

\section{Source}

National Cancer Institute. Z-DNA Binding Protein. NCI Thesaurus. Code C19548.

A protein which specifically binds to Z DNA 